\title{
Game mechanics and aesthetics differences for tangible and intangible goods provided via social media
}

\author{
Fortesa HAZIRI \\ Tomas Bata University, Zlin, Czech Republic \\ Haziri@Utb.Cz \\ Miloslava CHOVANCOVÁ \\ Tomas Bata University, Zlin, Czech Republic \\ Chovancova@Utb.Cz \\ Faton FETAHU \\ University "Hasan Prishtina”, Prishtinë, Republic of Kosovo \\ Fatonfetahu@Outlook.Com
}

\begin{abstract}
Companies aspire to fulfil consumers' needs, wants and desires by offering products and services. Due to globalization and digitization, the world became a small village by facilitating the obtainability of products/services across the globe. Furthermore, the online purchasing via social platforms mirrors the traditional purchasing process. Gamification, game techniques and elements have been employed in the different domain for engaging and motivating consumers, students, endusers in numerous countries and cultures. Gamification is considered the appliance of game techniques and game elements in the non-game environment. It's been adjusted in different models founded as a need to explore and explain variables, phenomena and theories. Game mechanics as one of the game elements are applied in different disciplines to achieve better performance, fruitful collaboration, active and enthusiastic participation, creating enjoyable, pleasurable and entertaining environment. Aesthetics are described as the sensory part that game evoke within the player. To identify the differences within consumers who purchase via social media when game mechanics and aesthetics are applied, the chi-square test for independence has been employed. The results estimate that the association between products and services as variables is not statistically significant and the relationship between them is weak or moderated. The findings of this research are useful for private companies and other interested stakeholders.
\end{abstract}

Keywords: aesthetics, game mechanics, online buying behaviour, products, services, social media, user behaviour.

\section{Introduction}

Tangible and intangible goods assist companies to obtain the aimed profit by fulfilling consumers' needs, desires and demand. Differences within products and services are beyond what is visible. However, the management literature is constantly providing evidence regarding the benefits of integrating services as a core product for manufacturing companies (Oliva \& Kallenberg, 2003). Services are hardly copied, therefore, companies would have the opportunity to create competitive advantages by being original and unique (Sasser, Schlesinger, \& Heskett, 1997). Due to globalization and digitization consumers are exposed to a wide range of choices. Namely, consumers face difficulty before deciding 
which product/service to choose. In social media are offered services and products from numerous companies across the globe. For research purpose, the authors have study gamification, game mechanics and aesthetics to identify the differences between purchasing products and services via social platforms. Gamification is a term which is used to describe the appliance of game elements into a non-game context (Seaborn \& Fels, 2015). Game mechanics and aesthetics are game elements which have been employ from MDA Framework.

Due to the lack of study in theoretical and practical scope for game mechanics and aesthetics and its differences for products and services in the consumer behaviour domain, this study has been conducted. To identify the differences within consumers who purchase via social media when game mechanics and aesthetics are applied has been established as a goal by authors. The study has been conducted in the Republic of Kosovo (hereinafter: Kosovo) with respondents who use social media for shopping products or services.

In this article, are presented the theoretical and practical contribution in the domain of consumer behaviour, game mechanics and aesthetics. The goal to conduct this research lies on three pillars, firstly, to explore the conceptual and theoretical characteristics of game mechanics and aesthetics to present the common view as a term and notion. Secondly, to provide information regarding the game mechanics and aesthetics appliance in different domains. Thirdly, to depict the connection between game mechanics, aesthetics and consumer buying behaviour when purchasing products and services via social media. In the first part of the paper, an analyse of aesthetics, game mechanics and gamification in general from the theoretical point of view is presented, by covering the aesthetics, game mechanics and gamification as evolving term, the attempts to present gamification as an applicable theory in the consumer behaviour domain by exploring the related and previous research. In the second part, is presented the methodology, methods, sample, survey and the procedure followed to conduct this research. In the third part, are summarized the results of the findings, followed by discussion. The last part of the paper includes the conclusion, implication and recommendations for future research.

\section{Game mechanics, aesthetics and e-consumers: Literature review}

Consumer behaviour and social media have been going through a lot of changes. Due to facilitating feature offered by social media consumers feel motivated to use them for purchasing purpose (Yahia, Al-Neama, \& Kerbache, 2018). Jankowski et al., (2016) analyzed the consumer behaviour changes for traditional and online purchasing behaviour. The study indicates that the decision-making process when purchasing online mirrors the traditional purchasing decision making process. Furthermore, the study points out that the reflection stands for the number of transactions. Beside facilitating features offered by social platforms, companies managed to obtain consumer trust and be a significant factor regarding purchasing final decision (Widodo, Yusiana, \& Anggi, 2017). However, purchasing fruit and vegetable consumers in Fukuoka go to supermarket compare to consumers in Shanghai and Taipei which visit traditional markets to purchase the products (Saito, Iwami, Nakashima, \& Chu, 2006). Notably, consumers for certain products/service feel confident purchasing them offline rather than via social platforms the behavioural changes were not identified. 
Purchasing products and services via social media might have similarities and dissimilarities. According to Dabija, Bejan and Tipi (2018) differences between generation X and Millennials for purchasing products and services lies on recommendation and personal preferences regarding information obtainability. Regarding the impact of the "Like" button on Facebook Pelletier and Blakeney Horky (2015) have study the untold story of brand liking on Facebook. The results indicated that no differences exist within brand knowledge when comparing products and services. Although, differences were identified for perceiving the brand relatedness between brand types. Moreover, consumers showed a high sense of linking to the services brand and for products, the linking was with brand attitude and purchase intention. The brand name for service messages is more likely to be popular, but for products the brand name, image and videos are more likely to be popular. And, comparing the number of comments, services tend to receive more comments than products (Swani \& Milne, 2017). But, is a totally different situation for Twitter users, comparing the negative comments received for services and products, services lead with a higher number of emotional negative comments (Hornikx \& Hendriks, 2015).

Gamification impact on education, employment motivation, project management has been explored widely. Game techniques and elements in game context have been proven to be successful in engaging and motivating for users' behaviour. Games, in general, obtain elements which engage the player to continue playing endlessly. Three gamification framework has been developed by using the same variables but named differently. Km and Lee (2015) have created MDA Framework by using game mechanics, game dynamics and aesthetics. Werbach and Hunter (2012) have designed a pyramid by the same elements, only aesthetics is different, he named them as components. The pyramid has components as the base element, game mechanics in the middle and game dynamics at the top. Additonally, Robson et al. (2015), has applied the same elements in his research but in instead of aesthetics he named them as emotions. In the game context, dynamics are described as the engaging and abstract concept part of the game, mechanics as the rules part of the game which must be followed by the player to achieve the desirable results and components as the beginning part of the game which includes the hook and tools that can be employed to incorporate the player into the game (Werbach \& Hunter, 2012). Gamification application in training (Alcivar \& Abad, 2016), learning motivation (Monterrat, Lavoué, \& George, 2017), employee motivation (Dale, 2014), promoting healthy lifestyle (Hamari \& Koivisto, 2015) and politics (Mahnic, 2014) has proven to be successful and if designed properly the benefits would be profitable.

Game mechanics, in the game context, are described as the set of rules and margins that the designer has specified for the player (Robson et al., 2015). Game mechanics are one of the elements of the MDA framework, which has been designed by Kim and Lee (2015). Additionally, game mechanics contain items such as level, points, leaderboards, goal, onboarding, quest, badges, virtual items or avatars and feedback. The elements have been used to engage and motivate end-users, students and consumers. In the educational domain, game mechanics applied for lectures, courses have been considered highly motivating and engaging. The study which has been conducted by Martin Poole, Kemp, Patterson and Williams (2014), emphasize the obtained benefits by game mechanics appliance. The findings show that in the class students had better performance, collaboration, the emotional status and more enthusiastic. Furthermore, Chang and Wei (2016) have identified virtual goods as gifts, redeemable points, team leaderboards, the 
Where's Wally game, trophies and badges as game mechanics tool for engaging and motivating Taiwanese students of massive open online courses. Engaging consumers in providing new ideas for organizations to be implemented later on has been studied by Scheiner (2015). The scholar further suggests that to have successful engagement with consumers game points, levels, avatars or virtual identity and badges should be designed and applied properly. The same positive effect has been identified in patients engagement (Hammedi, Leclerq, \& Van Riel, 2017). The psychological and arousal effect of digital badges is significant concerning modifying the information transmission, memorising and interaction according to receiver needs. Moreover, badges are employed when casual action should be engaged followed by chronological terms (McDaniel \& Fanfarelli, 2016). After consulting the literature the following hypothesis has been designed:

H1: The association between purchasing products or services via social media and game mechanics is not statistically significant.

Aesthetics is one of the MDA framework elements. According to the tetrad framework, aesthetics include elements which make the player feel the magnificent venture whereas other feelings might be evoked. The mentioned feelings can be induced within the game creative vision, visual semiotic, snapshot aesthetics and design aesthetics (Hofacker, Ruyter, Lurie, Manchanda, \& Donaldson, 2016). Although researchers present rewards as the engaging and motivating elements, consumers who find game display characteristics arousal exist as well (Hartmann, Jung, \& Vorderer, 2012). The centrality of visual product aesthetics features revealed are value, wisdom and response intensity. Although, the aesthetics are measured by consumer satisfaction, trustworthiness and rationality (Bloch, Brunel, \& Arnold, 2002). Players usually assume to create a better reality in the games. The workplace as a playground might not exist. However, puzzling the environment with aesthetics elements to provide the employees with the feeling of the gameful environment but the reality-like elements leads to better work results (Bateman, 2018). Regarding aesthetics elements impact towards engagement and motivation behaviour, pleasure is significantly positive in short and long periods although emotions revealed not to be important (Poels, Hoogen, Ijsselsteijn, \& de Kort, 2012). Game elements can assist consumers to resolve problems, take action and persuade consumers towards behavioural desireable changes (Ferrara, 2013). Aesthetics revealed to be significant and powerful tools concerning encouraging and engaging end-users (Suh, Cheung, Ahuja, \& Wagner, 2017). Regarding aesthetics significance the following hypothesis has been designed:

H2: The association between purchasing products or services via social media and aesthetics is not statistically significant.

\section{Methodology}

To gather data regarding game mechanics and aesthetics, ten statements have been developed. The game mechanics and aesthetics statements are designed based on the previous literature (Hamari, 2017; J. T. Kim \& Lee, 2015; Sigala, 2015; Werbach \& Hunter, 2012). They include items that express game mechanics such as fun, joy, rewards, points, badges, leaderboards. And, items that express aesthetics such as positive feelings, emotions, satisfaction and delight. To measure the level of agreement the five-point Likert scale (1Strongly disagree, 2-Disagree, 3-Neutral, 4-Agree, 5-Strongly agree) has been used. The first criteria to be part of the survey was to be a consumer who at least bought a product/service 
via social media. Beside ten statements regarding game mechanics and aesthetics items, the questionnaire contained a question regarding what consumers have purchased via social media. A closed-ended question with two options, products or services, was part of the questionnaire. Additionally, before submitting respondents had the opportunity to add a comment about the questionnaire or additional information regarding their buying experience. The study has been conducted in Kosovo, consumers who purchased via social media at least once, regardless of age, city and gender took part of the survey. Moreover, the questionnaire was distributed in all cities of Kosovo, which allows to generalize regarding results. 151 respondents were part of the questionnaire.

Table 1. The game mechanics and aesthetics statements

\begin{tabular}{|c|c|c|c|}
\hline Dimension & Item & Survey statement & Source \\
\hline \multirow{5}{*}{$\begin{array}{l}\text { Game } \\
\text { mechanics }\end{array}$} & GM01 & $\begin{array}{l}\text { By buying via social media, I am able to obtain } \\
\text { points, badges, and leader-boards }\end{array}$ & \multirow[t]{5}{*}{$\begin{array}{l}\text { (Haziri \& } \\
\text { Chovancova, } \\
\text { 2018) }\end{array}$} \\
\hline & GM02 & $\begin{array}{l}\text { The benefits received for buying via social } \\
\text { media are thrilling }\end{array}$ & \\
\hline & GM03 & $\begin{array}{l}\text { Purchasing via social media helps me forget } \\
\text { unpleasant events and makes me feel better } \\
\text { than others }\end{array}$ & \\
\hline & GM04 & $\begin{array}{l}\text { I felt motivated by the rewards, points and } \\
\text { badges offered by sellers }\end{array}$ & \\
\hline & GM05 & $\begin{array}{l}\text { Social media make shopping a fun and enjoyable } \\
\text { process }\end{array}$ & \\
\hline \multirow[t]{5}{*}{ Aesthetics } & AS01 & $\begin{array}{l}\text { I get very emotional regarding the way I interact } \\
\text { with everything while shopping via social media }\end{array}$ & \\
\hline & AS02 & $\begin{array}{l}\text { I felt like I was discovering a totally new world } \\
\text { while purchasing via social media }\end{array}$ & \\
\hline & AS03 & $\begin{array}{l}\text { Satisfaction and delight are the words to } \\
\text { describe my experience when shopping online }\end{array}$ & \\
\hline & AS04 & Buying online stimulates my fantasy & \\
\hline & AS05 & $\begin{array}{l}\text { The bond I feel with the products/items/goods } \\
\text { presented in social media is strong }\end{array}$ & \\
\hline
\end{tabular}

Source: Authors' development

To fulfil the aim of the research, the chi-square test for independence has been employed. The criteria to employ the chi-square test for independence have been fulfilled and the standard procedures have been followed. One of the criteria which is the variables to be nominal/categorical from a single population is accomplished. Also, due to the need to determine the association between variables chosen to be analysed. The frequency of each category for a nominal variable is compared with the opposite categories of the other nominal variable. Since chi-square does not provide information on whether the relationship between variables is strong or weak, the Cramer's V coefficient results have been followed (Tabachnick \& Fidell, 2014). The data have been analysed using SPSS version 23. 


\section{Results and discussion}

The questionnaire was distributed via social media groups. The group member were required to volunteer to fill the questionnaire. Previously they were informed regarding the aim and the reason to conduct this survey. The group members has different profile, different age and city distribution. Initially to be part of the survey the respondents had to purchase previously via social media. According to the Kosovo Business Registration Agency (hereinafter: ARBK) report (2018), in Kosovo are registered above 173 thousand businesses. Above 60 thousand of them are businesses in the trade domain. The businesses offer products, mostly imported from other countries. The majority of respondents of the questionnaire purchase products from social media $87.4 \%$ compare to services $12.6 \%$.

Table 2. Chi-Square results regarding products, services and game mechanics

\begin{tabular}{|c|c|c|c|}
\hline \multirow{2}{*}{$\begin{array}{c}\text { Items-game } \\
\text { mechanics }\end{array}$} & \multicolumn{2}{|c|}{ Chi-Square } & \multirow{2}{*}{ Cramer's V } \\
\cline { 2 - 3 } & $\chi^{2}(4)$ & $\mathrm{p}$-value & .136 \\
\hline GM01 & 2.783 & .595 & .099 \\
\hline GM02 & 1.467 & .833 & .139 \\
\hline GM03 & 2.904 & .574 & .088 \\
\hline GM04 & 1.161 & .885 & .208 \\
\hline GM05 & 6.541 & .162 & \multicolumn{2}{|c|}{ Source: Authors' own research } \\
\hline
\end{tabular}

Based on Table 2, the chi-square results for independence estimates that no significant association between products, services and obtaining points, badges, and leaderboards $\chi 2(4, \mathrm{n}=151), \mathrm{p}=.595$. Cramer's $\mathrm{V}=.136$, associating a weak relation between the variables. Rearding the second item of game mechanics, which describes the benefits of purchasing via social media and purchasing items according to results no association was identified $\chi 2(4, \mathrm{n}=151), \mathrm{p}=.833$. Cramer's V resulted with .099 signifying that is a small to moderate association between the item and the benefits of purchasing via social media. Concerning the third item related to the purchasing experience via social media and forgetting unpleasant events and goods, the results did not identify significant association $\chi 2$ (4, n=151), $\mathrm{p}=.574$. Regarding Cramer's V, which resulted .139, the strength of the association is weak. The fourth item request the respondents to rank the level of agreement whether they felt felt motivated by the rewards, points and badges offered by sellers and the purchased items, the results signify that the association is insignificant $\chi 2(4, n=151)$, $\mathrm{p}=.885$. Cramer's $\mathrm{V}=.088$ which indicates a low association. No significant association was identified between purchasing goods and shopping as fun and enjoyable experience $\chi 2$ (4, $\mathrm{n}=151$ ), $\mathrm{p}=.162$. Cramer's V resulted .208 estimating a small to moderate association. Hence, non of the item resulted to be statistically significant.

Table 3. Chi-Square results regarding products, services and aesthetics

\begin{tabular}{|c|c|c|c|}
\hline \multirow{2}{*}{ Items-aesthetics } & \multicolumn{2}{|c|}{ Chi-Square } & \multirow{2}{*}{ Cramer's V } \\
\cline { 2 - 4 } & $\chi^{2}(4)$ & $p$-value & .148 \\
\hline AS01 & 3.306 & .508 & .141 \\
\hline AS02 & 2.998 & .558 & .182 \\
\hline AS03 & 5.017 & .286 & \\
\hline
\end{tabular}




\begin{tabular}{|c|c|c|c|}
\hline AS04 & 7.164 & .127 & .218 \\
\hline AS05 & 3.151 & .533 & .144 \\
\hline
\end{tabular}

According to the results depicted in Table 3 , being emotional while shopping via social media and the association between products and services resulted insignificant $\chi 2$ (4, $\mathrm{n}=151), \mathrm{p}=.508$. Cramer's V resulted .148 associating a weak or moderated relation between the variables. The second item regarding the feeling of discovering a new world while shopping via social media and purchasing items, no association was identified $\chi 2$ (4, $\mathrm{n}=151$ ), $\mathrm{p}=.558$. Cramer's $\mathrm{V}$ resulted with .141 signifying that is a small to moderate association between the second item and the feeling of discovering a new world. Consumers who felt satisfaction and delight while shopping via social media and goods, no significant association was identified $\chi 2(4, \mathrm{n}=151), \mathrm{p}=.286$. Regarding Cramer's $\mathrm{V}$, which resulted .182 , the strength of the association is weak. Consumers whose fantasy were stimulated while shopping via social media and the purchased items, no significant association was noticed $\chi 2(4, n=151), p=.127$. Cramer's $V$ resulted .218 which indicates a low association. No significant association was identified between the bond that consumers felt with the item, whether a service or a product, presented in social media and the purchased goods $\chi 2$ (4, $n=151), p=.533$. Cramer's V resulted .144 estimating a small to moderate association.

As presented in previous tables at the chi-square results, the authors failed to reject the $\mathrm{H} 1$ and $\mathrm{H} 2$ hypothesis, due to not statistically significant found between the variables. Furthermore, the five-game mechanics items and five aesthetics items were not significantly associated ( $p>0.05$ ) with products and services. In the comment section of the questionnaire, respondents added as the main reason for not purchasing services due the insecurity felt while shopping via social media. Therefore, handling, touching, feeling the products is strongly related to confidence and surety of owning the product. Equally important, the feeling towards service purchasing is strongly related to safety and legal issues. Researchers (Díaz, Gómez, \& Molina, 2017) found evidence that internet users tend to purchase online, however, the online purchasing is a reflection of the offline purchasing experience (Wang, Cui, \& Li, 2014) and highly influenced by WOM along with interpersonal offline influence (Bigne, Andreu, Hernandez, \& Ruiz, 2018). Also consumers search online for information and then buy the product in the shop physically (Voorveld, Smit, Neijens, \& Bronner, 2016; Watabe, 2018) and product features dictate whether to purchase online or offline (Arce-Urriza \& Cebollada-Calvo, 2011). Also, individual factors, for instance, internet usage experience, age and intellect development followed by the product type, whether hedonic or utilitarian, impact the purchasing behaviour (Akalamkam \& Mitra, 2018). The settings when purchasing offline impact consumer purchasing decision, for instance, music in shops tend to increase the cash flow and stimulate a pleasant communication (Ferreira \& Oliveira-Castro, 2011). Lastly, the previous research work conducted regarding online and offline purchasing behaviour have found similar results with the comment wroten by respondents of the survey conducted in Kosovo, therefore, Kosovar consumers suspicious purchasing products or services via social platforms.

\section{Conclusion}

Game elements in general and game mechanics along with aesthetics have been explored in different domains. Regarding differences between services, products, game mechanics and 
aesthetics, to the authors' knowledge, no study was found. Nevertheless, the service features, described in the management literacy, such as hardly copied, originality and uniqueness were not significantly important for consumers in one of developing countries. Additionally, as have been proven for game mechanics and aesthetics as an engaging and motivating tool for purchasing behaviour, the feeling of safety, security, and word of mouth seems to be the crucial features considered before purchasing.

To identify the differences within consumers who purchase via social media when game mechanics and aesthetics are applied has been established as a goal by authors. Therefore, the results estimate that the association between the variables is not statistically significant and the relationship is weak or moderated. Social media, in general, are facilitating the sharing information process of consumers' opinion and experience regarding products and services. The effect of eWOM and the impact of influencer for purchasing products and services via social media, for consumers it induce deeper search, new information seeking, pass-along attitude, changing approach towards products and services and buying intention (J. Kim \& Lee, 2017). Hence, consumers are forced to be aware of and extend the gathering information phase before deciding which product/service to buy.

The findings of this research are useful for private companies, specifically for companies which are trying to sell their products/services via social media. Therefore, this research creates a value-added for aesthetics, game mechanics, gamification, social media and consumer behaviour literature. Although, the study results might obtain implications for researchers and practitioners. For researchers, this study provides the initial information to in-depth analysis regarding game mechanics and aesthetics. MDA framework resembles to be an important and complete theoretical framework to be employed when analysing game elements, identifying the significant and substantial elements to achieve the desired effect it is always a noteworthy effort. For practitioners, is important to understanding the crucial items appliance of the framework, adjusting and applying according to the companies needs to yield consumer engagement and motivation. By understanding the leading game elements influencing consumer behaviour towards purchasing decision, constraints, and particularities, those concerned with game mechanics and aesthetics items impact, retailing companies will be able to advance, adjust functionalities according to customers' needs, adopt marketing strategies and integrating consumer communication tools.

Similar to other research work, this study has its limitations. The authors suggest investigating further by adding additional moderator such as age, social platform, city, working place, incomes or upgrade and modify the framework by adding other game elements. Furthermore, the same study might be conducted in other countries, whether developed or developing the country in order to identify the game elements impact consumer behaviour. Also, comparing the game elements impact by exploring cultures differences might lead to attractive results. Lastly, regardless industry the framework might be applicable, therefore, it would be stimulating to study the industry differences within the same framework and game elements. 


\section{Acknowledgement}

The authors are thankful for the financial support provided by the Internal Grant Agency of Tomas Bata University in Zlin, no. IGA/FaME/2018/2020: Consumer behaviour changes and entrepreneurship for market development through digitization.

\section{References}

Agjencia e Regjistrimit të Bizneseve të Kosovës. (2018). Raporti i indikatorëve bazë të performancës për regjistrimin e bizneseve në Kosovë për periudhën: Tetor - Dhjetor 2017. Prishtinë. Retrieved from https://arbk.rks-gov.net/desk/inc/media/37DB78E5BC9A-4179-9E0E-83A81D0DAB18.pdf

Akalamkam, K., \& Mitra, J. K. (2018). Consumer Pre-purchase Search in Online Shopping: Role of Offline and Online Information Sources. Business Perspectives and Research, 6(1), 42-60. https://doi.org/10.1177/2278533717730448

Alcivar, I., \& Abad, A. G. (2016). Design and evaluation of a gamified system for ERP training. Computers in Human Behavior, 58, 109-118. https://doi.org/10.1016/j.chb.2015.12.018

Arce-Urriza, M., \& Cebollada-Calvo, J.-J. (2011). A comparison of consumer behavior in online and offline channels: Price sensitivity, brand loyalty, and product characteristics effect. Cuadernos de Economía y Dirección de La Empresa, 14(2), 102-111. https://doi.org/10.1016/j.cede.2011.02.009

Bateman, C. (2018). Playing work, or gamification as stultification. Information, Communication \& Society, 21(9), 1193-1203. https://doi.org/10.1080/1369118X.2018.1450435

Bigne, E., Andreu, L., Hernandez, B., \& Ruiz, C. (2018). The impact of social media and offline influences on consumer behaviour. An analysis of the low-cost airline industry. Current Issues in Tourism, 21(9), 1014-1032. https://doi.org/10.1080/13683500.2015.1126236

Bloch, P. H., Brunel, F. F., \& Arnold, T. J. (2002). Individual Differences in the Centrality of Visual Product Aesthetics: Concept and Measurement. Journal of Consumer Research, 29(4), 551-565. https://doi.org/10.1086/346250

Chang, J. W., \& Wei, H.-Y. (2016). Exploring Engaging Gamification Mechanics in Massive Online Open Courses. Educational Technology \& Society, 19(2), 177-203. Retrieved from https://search.proquest.com/docview/1792129422?accountid=15518

Dabija, D.-C., Bejan, B. M., \& Tipi, N. (2018). Generation X versus Millennials communication behaviour on social media when purchasing food versus tourist services. $E+M$ Ekonomie a Management, 21(1), 191-205. https://doi.org/10.15240/tul/001/2018-1013

Dale, S. (2014). Gamification: Making work fun, or making fun of work? Business Information Review, 31(2), 82-90. https://doi.org/10.1177/0266382114538350

Díaz, A., Gómez, M., \& Molina, A. (2017). A comparison of online and offline consumer behaviour: An empirical study on a cinema shopping context. Journal of Retailing and Consumer Services, 38, 44-50. https://doi.org/10.1016/j.jretconser.2017.05.003

Ferrara, J. (2013). Games for Persuasion: Argumentation, Procedurality, and the Lie of Gamification. Games and Culture, 8(4), 289-304. https://doi.org/10.1177/1555412013496891 
Ferreira, D. C. S., \& Oliveira-Castro, J. M. (2011). Effects of background music on consumer behaviour: behavioural account of the consumer setting. The Service Industries Journal, 31(15), 2571-2585. https://doi.org/10.1080/02642069.2011.531125

Hamari, J. (2017). Do badges increase user activity? A field experiment on the effects of gamification. Computers in Human Behavior, 71, 469-478. Retrieved from https://ac.els-cdn.com/S0747563215002265/1-s2.0-S0747563215002265main.pdf?_tid=42f48541-2cd1-4fb7-98a33f9fc925229c\&acdnat=1538692928_329862c4852fac7399dbbbe69424711a

Hamari, J., \& Koivisto, J. (2015). “Working out for likes": An empirical study on social influence in exercise gamification. Computers in Human Behavior. https://doi.org/10.1016/j.chb.2015.04.018

Hammedi, W., Leclerq, T., \& Van Riel, A. C. R. (2017). The use of gamification mechanics to increase employee and user engagement in participative healthcare services. Journal of Service Management, 28(4), 640-661. https://doi.org/10.1108/JOSM-04-2016-0116

Hartmann, T., Jung, Y., \& Vorderer, P. (2012). What Determines Video Game Use? Journal of Media Psychology, 24(1), 19-30. https://doi.org/10.1027/1864-1105/a000059

Haziri, F., \& Chovancova, M. (2018). Game mechanics differences for Kosovars social media purchasers. In K. H. Rozana Veselica, Gordana Dukic (Ed.), Economic and Social Development - 36th International Scientific Conference on Economic and Social Development - "Building Resilient Society" (pp. 141-149). Zagreb: Varazdin Development and Entrepreneurship Agency. Retrieved from http://www.esdconference.com

Hofacker, C. F., Ruyter, K. de, Lurie, N. H., Manchanda, P., \& Donaldson, J. (2016). Gamification and Mobile Marketing Effectiveness. Journal of Interactive Marketing, 34, 25-36. https://doi.org/10.1016/j.intmar.2016.03.001

Hornikx, J., \& Hendriks, B. (2015). Consumer Tweets about Brands: A Content Analysis of Sentiment Tweets about Goods and Services. Journal of Creative Communications, 10(2), 176-185. https://doi.org/10.1177/0973258615597406

Jankowski, J., Kolomvatsos, K., Kazienko, P., \& Wątróbski, J. (2016). Fuzzy Modeling of User Behaviors and Virtual Goods Purchases in Social Networking Platforms. Journal of Universal Computer Science, 22(3), 416-437. Retrieved from https://pdfs.semanticscholar.org/e5fd/e4cb9b1df20a3b015a3bc863e22da19b2f6b.pd $\mathrm{f}$

Kim, J., \& Lee, C. (2017). Examining the role of relationship factors on eWOM effectiveness in social media. International Journal of Internet Marketing and Advertising, 11(2), 103123. https://doi.org/10.1504/IJIMA.2017.084078

Kim, J. T., \& Lee, W.-H. (2015). Dynamical model for gamification of learning (DMGL). Multimedia Tools and Applications, 74(19), 8483-8493. https://doi.org/10.1007/s11042-013-1612-8

Mahnic, N. (2014). Gamification of politics: start a new game! Teorija in Praksa, 51(1), 143161,190. Retrieved from https://www.fdv.uni-lj.si/docs/defaultsource/tip/tip_1_2014_mahnic.pdf?sfvrsn=0

Martin Poole, S., Kemp, E., Patterson, L., \& Williams, K. (2014). Get your head in the game: using gamification in business education to connect with generation Y. Journal for Excellence in Business Education, 3. Retrieved from https://repository.usfca.edu/ml/7 McDaniel, R., \& Fanfarelli, J. (2016). Building Better Digital Badges: Pairing Completion 
Logic With Psychological Factors. Simulation \& Gaming, 47(1), 73-102.

https://doi.org/10.1177/1046878115627138

Monterrat, B., Lavoué, É., \& George, S. (2017). Adaptation of Gaming Features for Motivating Learners. Simulation \& Gaming, 48(5), 625-656.

https://doi.org/10.1177/1046878117712632

Oliva, R., \& Kallenberg, R. (2003). Managing the Transition from Products to Services. International Journal of Service Industry Management, 14, 160-172. https://doi.org/10.1108/09564230310474138

Pelletier, M. J., \& Blakeney Horky, A. (2015). Exploring the Facebook Like: a product and service perspective. Journal of Research in Interactive Marketing, 9(4), 337-354. https://doi.org/10.1108/JRIM-09-2014-0059

Poels, K., Hoogen, W. van den, Ijsselsteijn, W., \& de Kort, Y. (2012). Pleasure to Play, Arousal to Stay: The Effect of Player Emotions on Digital Game Preferences and Playing Time. Cyberpsychology, Behavior, and Social Networking, 15(1), 1-6. https://doi.org/10.1089/cyber.2010.0040

Robson, K., Plangger, K., Kietzmann, J. H., McCarthy, I., \& Pitt, L. (2015). Is it all a game? Understanding the principles of gamification. Business Horizons, 58(4), 411-420. https://doi.org/10.1016/J.BUSHOR.2015.03.006

Saito, S., Iwami, M., Nakashima, T., \& Chu, X. (2006). An International Comparison of Daily Shopping Behavior among Shanghai, Taipei, and Fukuoka. Studies in Regional Science, 36(1), 223-239. https://doi.org/10.2457/srs.36.223

Sasser, W. E., Schlesinger, L. A., \& Heskett, J. L. (1997). Service Profit Chain. New York: Free Press. Retrieved from https://books.google.cz/books?id=f8PpwCgtp9MC\&dq=Heskett,+J.L., + Sasser, + W.E. + an $\mathrm{d}+$ Schlesinger,+L.A.+(1997),+The+Service+Profit+Chain,+Free+Press,+New+York,+NY. $\& l r=\&$ source $=$ gbs_navlinks_S

Scheiner, C. W. (2015). The Motivational Fabric of Gamified Idea Competitions: The Evaluation of Game Mechanics from a Longitudinal Perspective. Creativity and Innovation Management, 24(2), 341-352. https://doi.org/10.1111/caim.12115

Seaborn, K., \& Fels, D. I. (2015). Gamification in theory and action: A survey. International Journal of Human-Computer Studies, 74, 14-31. https://doi.org/10.1016/J.IJHCS.2014.09.006

Sigala, M. (2015). The application and impact of gamification funware on trip planning and experiences: the case of TripAdvisor's funware. Electronic Markets, 25(3), 189-209. https://doi.org/10.1007/s12525-014-0179-1

Suh, A., Cheung, C. M. K., Ahuja, M., \& Wagner, C. (2017). Gamification in the Workplace: The Central Role of the Aesthetic Experience. Journal of Management Information Systems, 34(1), 268-305. https://doi.org/10.1080/07421222.2017.1297642

Swani, K., \& Milne, G. R. (2017). Evaluating Facebook brand content popularity for service versus goods offerings. Journal of Business Research, 79, 123-133. https://doi.org/10.1016/j.jbusres.2017.06.003

Tabachnick, B. G., \& Fidell, L. S. (2014). Using multivariate statistics (6th edition). Harlow: Pearsom Education Limited.

Voorveld, H. A. M., Smit, E. G., Neijens, P. C., \& Bronner, F. E. (2016). Consumers' CrossChannel Use in Online and Offline Purchases: An Analysis of Cross-Media And CrossChannel Behaviors between Products. Journal of Advertising Research, 56(4), 385-400. 
https://doi.org/10.2501/JAR-2016-044

Wang, L., Cui, Y., \& Li, Y. (2014). Impact of consumers' offline experience on their online search intentions and search behavior: An empirical study of college students. Wuhan Daxue Xuebao (Xinxi Kexue Ban)/Geomatics and Information Science of Wuhan University, 39, 26-30.

Watabe, K. (2018). Comparative analysis and modeling of two consumer types based on the frequency of $\mathrm{O} 2 \mathrm{O}$ behaviors, and suggestions to motivate consumers from online to offline shopping. Journal of Japan Industrial Management Association, 69(2), 61-76. https://doi.org/10.11221/jima.69.61

Werbach, K., \& Hunter, D. (2012). For the win: how game thinking can revolutionize your business. Wharton Digital Press .

Widodo, A., Yusiana, R., \& Anggi, S. (2017). How E-marketing and trust influence online buying decision: A case study of mataharimall.com in Bandung. Pertanika Journal of Social Sciences and Humanities, 25(August), 107-114. https://doi.org/10.1108/02634500210431595

Yahia, I. Ben, Al-Neama, N., \& Kerbache, L. (2018). Investigating the drivers for social commerce in social media platforms: Importance of trust, social support and the platform perceived usage. Journal of Retailing and Consumer Services, 41, 11-19. https://doi.org/10.1016/j.jretconser.2017.10.021 